Journal of Development and Communication Studies, Vol. 8. No. 2, July -December, 2021 ISSN (Online \& Print): 2305-7432. http://www.devcomsjournalmw.org

\title{
Herbicide toxicity awareness among smallholder farmers and agriculture extension officers in Malawi
}

Levi Zeleza Manda, Blantyre International University, Blantyre, Malawi.

Email: 1manda@biu-edu.comＯRCID iD: https://orcid.org/0000-0001-8923-2657

\begin{abstract}
Using evidence from field key informant and written questionnaire interviews with agriculture extension officers, focus group discussions with some smallholder farmers, analysis of packaging labels, and a detailed literature review, this paper argues that Malawian smallholder farmers handle herbicides without adequate information about the advantages and negative impacts of such herbicides because, it appears, the agriculture extension workers themselves lack requisite knowledge on herbicide toxicity. Further, the study finds that herbicides are marketed in Malawi in breach of Malawian law and in contravention of the Rotterdam Convention as the information on the herbicide labels is sometimes inadequate, misleading, and unavailable in local languages. This exposes farmers to potentially carcinogenic chemicals without their knowledge. The paper recommends, inter alia, that an awareness campaign about the long term harmful effects of herbicides be mounted countrywide and internationally to protect illiterate smallholder farmers from herbicide toxicity.
\end{abstract}

Keywords: conservation agriculture, glyphosate, herbicide toxicity, public health awareness campaign, Malawi

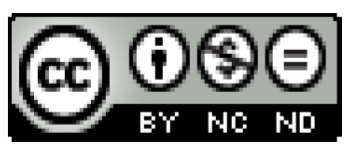

(C) 2021. The author. This work is licensed under the Creative Commons Attribution 4.0 International License (CC-By-NC-ND). Users may freely share and redistribute this work provided that the author and the Journal of Development and Communication Studies are fully acknowledged. Users may not tweak or remix and offer this work for sale. The full license may be accessed at https://creativecommons.org/licenses/by-nc$\mathrm{nd} / 4.0 /$

To cite this article: Manda, L.Z (2021), Herbicide toxicity awareness among smallholder farmers and agriculture extension officers in Malawi, Journal of Development and Communication Studies, 8(2), 85-94, https://dx.doi.org/10.4314/jdcs.v8i2.6 


\section{Introduction}

Since the mid-2000s when Malawi started promoting conservation agriculture, smallholders, who produce over 80 percent of Malawi's food (Malawi Government, 2016), have increasingly taken to relying on herbicides to keep their fields free of weeds.

The Malawi Government (2019) lists over 160 approved herbicides, 62 of which, including Harness, Roundup and Dual Magnum 960, and Stellar Star, are applicable in maize (corn), Malawi's staple food crop. Others are reserved for application in food crops such as soy beans, groundnuts, and sugarcane. None of the herbicides used in Malawi is made or packaged in Malawi. In tandem with the UN's Rotterdam Convention on Prior Informed in the use of Harmful pesticides, on The Pesticide Act of 2000/2012 and the Twelfth Schedule of the Pesticide Regulations of 2016 prescribe that all pesticides, including herbicides, must have clear instructions and counter indications in English and any one or more local languages. Precisely, Section 29 of the Pesticides Act 2000/2012 prescribes as follows:

(2) The text of the label and of any publication relating to a pesticide which is intended to be distributed or displayed with the pesticide shall be in English and in any other language or languages spoken in Malawi which the Board may require, and shall comply with such other requirements as may be prescribed.

The foregoing is in line with Article 13 of the UN's The Rotterdam Convention on the Prior Informed Consent Procedure for Certain Hazardous Chemicals and Pesticides in International Trade (1998), which regulates use of certain hazardous chemicals and pesticides. It says:

(5). The information on the label and on the safety data sheet should, as far as practicable, be given in one or more of the official languages of the importing Party.

This study set out to a) find out prevalently stocked herbicides in agrochemical shops, b) retailer, smallholder farmer, and agriculture extension officer awareness and knowledge of herbicide toxicity, and c) adherence to the law by herbicide manufacturers and marketers.

\section{Methodology}

Field research for this study was conducted in May 2018. First, a literature review on the toxicity of approved herbicides was undertaken to summarise the international debate on herbicide toxicity. To understand their knowledge on the advantages and disadvantages of the said herbicides, a focus group discussion with Mleranthaka smallholder farmers club in Mdeka, Lirangwe Extension Planning Area (EPA), Blantyre, Malawi and key informant interviews were conducted with two lead/model farmers and the agriculture extension officer for the said EPA. 
Nineteen District Agricultural Development Officers from around Malawi were interviewed through an eight-item questionnaire. Also interviewed for the same purpose were herbicide retailers in Lilongwe, Ntcheu, and Blantyre. Finally, samples of packaging labels of Roundup, Glyphosate, Harness, Dual Magnum 960, and Stellar Star were examined to learn if they were in conformity with s.29 (2) of the Pesticide Act of 2000/2012.

Data analysis took the form of qualitative textual and thematic analysis (Kvale, 1996; Flick 2007; Marshall \& Rossman, 2016).

\section{Findings and Discussion}

\section{Prevalent herbicides}

The author interviewed herbicide retailers in Lilongwe, Ntcheu, and Blantyre where the herbicides were sold off the shelf and without the retailers wearing personal protective equipment (PPE) such as face masks, hand gloves, or overalls. The most commonly stocked herbicide brands included: Glyphosate 480 EC, Roundup, Acetochlor 900 EC, Harness, Dual Magnum 960 EC, and Stellar Star.

In 2019 glyphosate was banned in Malawi (see Sustianable Pulse, 2019). This banning of glyphosate products was interpreted as a start to ensuring the health of the public and samllholder farmers. However, for many people, their lives have already been turned upside because of this dangerous chemical. However, despite being banned, Roundup and other glyphosate herbicide brands are still being sold off the counter in agrochemical shops we visited across Malawi.

\section{Knowledge of advantages and disadvantages of herbicides}

\section{Retailers and farmers}

The herbicide retailers had good practical knowledge of herbicide application methods of and reported that they informed buyers how to apply the herbicides. As for the advantages, all mentioned labour and money saving, and ease of use. The only disadvantage they mentioned was skin irritation "typical of agricultural chemicals" (Lead Farmer, Mdeka; Hercide Seller, Ntcheu, personal communication).

Like herbicide retailers, farmers in Mdeka only reported minor effects on their bodies, such as itching or irritation. Asked about the toxicity of the herbicides one lead farmer said:

"We regularly use herbicides like Roundup, Harness, Stellar (Star)....our extension officer (name withheld) here (pointing at him) has never told us about the toxicity of the herbicides... and since I started applying them in my field four years ago I have never experienced any serious problem... and never heard anyone complain except about itching here and there; which is normal."

This clearly indicates that the herbicide stockists/retailers and farmers were not aware of the carcinogenicity debate surrounding the herbicides, such as cancers, tumours, and 
organ failure reported by many studies including those by Séralini et al., (2014) who studied the impact of Roundup-infused maize on rats. Ruiz-Toledo (2014) and Clair et al. (2011) reported that even when diluted, Monsanto's Roundup herbicide contaminated surface water, damaged testicular cells leading to testosterone decrease, and eventual male infertility. Other studies reveal that human beings that had been exposed to excessive Roundup herbicide suffered heart failure, blurred vision, blood cancer of the lymph tissues, leukemia, liver, and pancreas damage, and skin rashes (Robin, 2008; African Centre for Biosafety, 2012). The African Centre for Biosafety, (2012) found inter alia that

1. "Glyphosate has become synonymous with genetically modified (GM) crops and. Though insect resistant (Bt) crops were initially the principally adopted GM crops, herbicide tolerant maize now accounts for 50\% of all GM maize planted in South Africa

2. “.... glyphosate based herbicides (GBH): have been linked to increased incidences of over 30 plant diseases, can inhibit nutritional uptake in plants, is toxic to earthworms and contributes significantly to incidences of fungal disease. Glyphosate's impact on weed diversity has knock on effects higher up the food chain, including on butterfly and bird populations

3. "... studies conducted in both the USA and Europe have detected high concentrations of both glyphosate and its main breakdown product, aminomethylphosphonic acid (AMPA) in groundwater sources, with considerable implications for drinking water supplies

4. "...once mobile in water, research has shown that glyphosate causes considerable damage to populations of amphibians, and is toxic to numerous aquatic organisms, including phytoplankton and freshwater mussels," (African Biosafety Centre, 2015, pp. 5-6) ${ }^{1}$

Reylea (2012) adds that glyphosate, the active ingredient in Roundup is also known to cause vertebrate morphological changes (Reylea, 2012) while Barrett (2014) notes that thirty years of research indicates that Roundup could be causing blood cancers and nonHodgkin lymphoma. Thongprakaisang et al. (2013) found a positive association between exposure to glyphosate and breast cancers in women and increased "estrogenic activity", (p.10). According to Rettner and Szalay (2014), estrogen is responsible for female characteristics and controls menstruation, lactation, but promotes tumour growth in breasts.

However, Monsanto (2014a), producers of the Roundup and other glyphosate chemical herbicides, claims its products are safe and nontoxic. Its claims are backed by equally authoritative studies. For example, Monsanto quotes Williams et al. (2016) as declaring that unless Roundup was intentionally consumed in large amounts $(>41 \%)$, the weed killer was nontoxic and non-carcinogenic. An evaluation by the Australian

\footnotetext{
1 https://www.acbio.org.za/sites/default/files/2015/02/Roundup-EnvironmentalimpactsSA.pdf
} 
Pesticides and Veterinary Medicines Authority (APVMA) concluded that, based on its assessment of scientific evidence available, "exposure to glyphosate does not pose a carcinogenic risk to humans" APVMA (2017, p.38).

Nonetheless, on the strength of the evidence against the use of glyphosate-based herbicides, 20 countries, including France, Russia, Italy, and Sri Lanka and 25 States in the USA banned glyphosate (Carlson Law Firm, 2021). Curiously, Malawi was listed also as having banned glyphosate-based herbicides (see Sustainable Pulse, 2019) but application of the herbicide went on, nonetheless.

During the Focus Group discussions with Mleranthaka Smallholder Farmers Club members in Keyala Village, Traditional Authority Chigalu, Mdeka, Blantyre, it was learnt that the discussants regularly used the herbicides and were happy about their effects in maize fields. They argued that the technology was cost effective and labour saving. Likewise, farmers in conservation farming trials implemented in Balaka and Salima districts in Malawi by the Sustainable Intensification of Maize-Legume Systems for Food Security in Eastern and Southern Africa (SIMLESA) are reported to have also praised the glyphosate weed clearing technology (SIMLESA 2014a; 2014b).

Concern Universal Malawi (2011) reports that Malawi's National Conservation Agriculture Task Force (NCATF) had recommended that farmers use chemical fertilizers, minimum-tillage and herbicides such as Harness in combination with glyphosate as a panacea to climate change challenges the farmers faced. Dual Magnum 960 EC by Syngenta is also applied in combination with Roundup or Stellar Star as an alternative to Harness to kill more weeds than what Roundup, Harness, or Dual Magnum alone can. Dual Magnum 960 EC contains metolachlor, which reportedly, causes several ailments in human beings and contaminates water systems (see Rosenfeld \& Feng, 2011).

Following field demonstrations of herbicidal weeding and preplanting burn-down with Harness (Acetochlor), Bullet (Alachlor + Atrazine), and Roundup (glyphosate) in Lilongwe, Malawi, farmers were reported to have been impressed with the demonstrations and most planned to adopt the technology (Gianessi and Kiingi 2009). The report does not mention teaching farmers about the toxicity of the herbicides.

\section{Agriculture extension and development officers}

The agriculture extension officer for the area reported that while he understood the advantage of using herbicides in conservation agriculture, such as reduced labour cost and reduced field clearing and weeding time, he had not heard much about any serious adverse effects of the herbicides used by his farmers. Similarly, responses to a written questionnaire by 19 purposively selected district agriculture development officers, who are much more senior than EPA level agriculture extension officers, yielded similar lack of knowledge about the negative effects of the herbicides on humans. 


\section{Conformity to Malawian law and the Rotterdam Convention}

On its marketing blurb, users are informed that Roundup a) does not bio-accumulate in the soil and or the food chain, b) is broken down in the soil by microorganisms into nitrates, phosphates, carbon dioxide and water; and c) is not metabolised by animals, humans, fish, birds, replies, vertebrates and invertebrates - it only affects plants. No known toxicity information is provided.

This information could be misleading because it gives the impression of a totally innocent and nontoxic product, yet studies reviewed indicate otherwise. Contrary to Monsanto's (2014) claims, the African Centre for Biosafety (2012), Marin-Morales et al. (2013), and Kughur (2012) have severally observed that glyphosate accumulates in the soil and is highly soluble in water and negatively affects crops.

In total contravention of the S.29 (2) of Malawi's Pesticides Act 2000/2012 and Article 13(5) of the Rotterdam Convention (UN 1998), the herbicides are marketed without translations in local languages. The instructions are either in English only, English and Afrikaans (if produced and packaged in South Africa), or English and kiSwahili (if produced in East Africa), meaning that the products being used and sold in Malawi were not meant to be used in Malawi.

\section{Conclusion and Recommendations}

In Malawi, farmers, and to some extent extension officers/agricultural officers and retailers, handle herbicides without being fully informed about the chemical technology's adverse effects. The key informant interviews, focus group discussions, and written questionnaire responses reveal that neither smallholder famers, retailers nor extension officers/agricultural officers are aware of the toxicity controversy associated with the herbicides wantonly used in Malawi. The study has found that the herbicides are being marketed in contravention of the laws of Malawi, which demand that instructions and known counterindications of any pesticide, including herbicides, be available in local languages or in English and any target local language.

The study recommends that extension officers and district agricultural be immersed in communication for development techniques for them to better understand the research relating to herbicide technologies so that they effectively inform their farmers (see Forget, 1991; Agunga and Manda, 2014), and urges herbicide oversight and regulatory agencies to ensure the laws of Malawi, particularly, s.29 of the Pesticides Act of 2000/2012, and the Rotterdam Convention (Article 13 (5), are strictly adhered to. To ensure Malawian farmers are fully informed about the risks posed by the agrochemicals, including herbicides, an extensive multimedia public health awareness campaign on agrochemicals should be conducted. All food crops produced using the herbicide weeding technology must be labelled as such so that consumers make informed choices when purchasing. No herbicide is nontoxic to humans in the long term. Deliberate 
exposure of unsuspecting farmers to dangerous chemicals breaches the biomedical ethical principle of non-malfeasance (Kuzma, 2017).

\section{Acknowledgments}

The author acknowledges review comments by Prof Mtafu Chinguwa Manda, Mzuzu University, Malawi and Grey James Mang'anda, Dean of Academics, Blantyre International University, Malawi.

\section{Conflict of Interest}

The author declares that he has no conflict of interest. Personal resources were used in the gathering of data for the study.

\section{References}

Agunga, R. \& Manda, L.Z. (2014), Communication for strengthening agricultural extension and rural development in Malawi. Journal of Development and Communication Studies, 3(1) https://www.ajol.info/index.php/jdcs/article/view/112348/102102 (Accessed 11 March 2021)

African Biosafety Centre (2012), Glyphosate in SA- Risky pesticides at large and unregulated in our soil and water. Melville: African Centre for Biodiversity. https://www.acbio.org.za/glyphosate-sa-risky-pesticide-largeand-unregulatedour-soil-and-water (Accessed 20 April 2021)

Australian Medicines and Veterinary Medicines Authority (APVMA) 2017. Final regulatory position: Consideration of the evidence for a formal reconsideration of glyphosate. https://apvma.gov.au/sites/default/files/publication/26561-glyphosatefinalregulatory-position-report-final_0.pdf. (Accessed 19 April 2021)

Barrett, M. (2014), Meta-Analyses Finds Link Between Glyphosate and Cancer of the Lymph Tissue. Natural Society. http://naturalsociety.com/metaanalyses-findsassociation-glyphosate-cancer-lymphtissue/\#ixzz3Ts4RP03R (Accessed 9 March 2015).

Carlson Law Firm (2021), Which countries and US States are banning Roundup? https://www.carlsonattorneys.com/news-and-update/banningroundup. (Accessed 21 April 2021).

Clair, E. Mesnage, R, Carine T., \& Séralini, G-C (2011), A glyphosate-based herbicide induces necrosis and apoptosis in mature rat testicular cells in vitro, and testosterone decrease at lower levels. Toxicology in Vitro 26(2):269-79. https://www.sciencedirect.com/science/article/abs/pii/S0887233311003341? via\%3Dihub. (Accessed 11 March 2021)

Flick, U. (2007). Designing Qualitative Research. London: SAGE Forget, G. (1991) Pesticides and the Third World. Journal of Toxicology and Environmental Health, 32 (1), 11-32. 
https://www.tandfonline.com/doi/ref/10.1080/15287399109531462?scroll=t op. (Accessed 20 April 2021)

Gianessi, L. and Kiingi, S (2009) Demonstrating the Value of Herbicides for Smallholder African Farmers Summary of Year One Project Activities.

https://croplifefoundation.files.wordpress.com/2012/05/africa-year-1progress.pdf. (Accessed 11 April 2021)

Kughur, PG (2012), The Effects of herbicides on crop production and environment in Markudi Local Government Area of Benue State, Nigeria. Journal of Sustainable Development in Africa, 14 (4), 206-216

https://www.researchgate.net/publication/280556081_the_effects_of_herbi cides_on_crop_production_and_environment_in_makurdi_local_governme nt_area_of_benue_state_nigeria. (Accessed 10 April 2021)

Kuzma, J. (2017), Society and Policy Maker's Responsibilities. In Emilien, G., Wetkunat, R. \& Lüdicke, F. (eds.), Consumer Perception of Product Risks and Benefits (547-566):

Berlin: Springer:

Kvale, S. (1996), Interviews: An Introduction to Qualitative Interviewing.

Thousand Oaks: SAGE.

Malawi Government (2012), Pesticides Act, CAP 35:03. Lilongwe: Ministry of Justice. Malawi Government (2016), National Agriculture Policy. Lilongwe: Ministry of Agriculture and Water Development.

Malawi Government (2019), Malawi Gazette Notice Number 26. Lilongwe: The Government Printer.

Marin-Morales, M. Ventura-Camargo, B, de C. Hishoma, M.Y. (2013). Toxicity of Herbicides: Impact on Aquatic and Soil Biota and Human Health.

https://www.intechopen.com/books/herbicides-current-research-and-casestudies-inuse/toxicity-of-herbicides-impact-on-aquatic-and-soil-biota-andhuman-health.

(Accessed 21 April 2021)

Marshall, C \& Rosman, G.B. (2016), Designing Qualitative Research. Los Angeles: SAGE

Monsanto (2014). Backgrounder Summary of Human Risk Assessment and Safety Evaluation on Glyphosate and Roundup Herbicide.

http://www.monsanto.com/glyphosate/documents/summary-of-humanriskassessment-and-safety-evaluation.pdf. (Accessed 11 March, 2015)

Relyea, RA. (2012), New effects of Roundup on amphibians: Predators reduce herbicide mortality; herbicides induce antipredator morphology. Ecological Applications, 22(2), pp.634- 647.

https://pubmed.ncbi.nlm.nih.gov/22611860/ (Accessed 10 February 2021)

Rettner, R \& Szalay, J. What is estrogen? http://www.livescience.com/38324what-isestrogen.html. (Accessed 10 March 2014)

Robin, M-M., (2008). The World According to Monsanto (video).

https://www.youtube.com/watch?v=dfNdej5hoVA. (Accessed 11 June 2019)

Rosenfeld, P.E., \& Feng, L.G.H., (2011) Pesticides. In Risks of Hazardous Wastes. https://www.sciencedirect.com/topics/earth-and-planetarysciences/metolachlor 
Ruiz-Toledo, J., Castro, R., Rivero-Pérez, N. et al. (2014) Occurrence of Glyphosate in Water Bodies Derived from Intensive Agriculture in a Tropical Region of Southern Mexico. Bull Environ Contam Toxicol, 93: 289-293.

https://doi.org/10.1007/s00128-014-1328-0 (Accessed 11 April 2021)

Séralini, G.E. Clair, E., Mesnage, R. et al. (2014), Republished study: longterm toxicity of a Roundup herbicide and a Roundup-tolerant genetically modified maize. Environ Sci Euro, 26(1):14. doi: 10.1186/s12302-014-0014-5. (Accessed 20 March 2021) SIMLESA (2014A), Farmers in Balaka, Malawi, prefer Ca.

https://simlesa.cimmyt.org/farmers-in-balaka-malawi-prefer-ca/. (Accessed 19 April 2021)

SIMLESA (2014B), Malawian Farmer Happy To Be Part of Simlesa.

https://simlesa.cimmyt.org/malawian-farmer-happy-to-be-part-of-simlesa/. (Accessed

19 April 2021)

Thongprakaisang, S., Thiantanawat, A., Rangkadilok, N., Suriyo, T., \& Satayavivad, J. (2013). Glyphosate induces human breast cancer cells growth via estrogen receptors. Food and Chemical Toxicology, 59: 129-36. Doi:

http//:10.1016/j.fct.2013.05.057. (Accessed 8 March 2015)

United Nations (UN). (1998), The Rotterdam Convention on the Prior Informed

Consent Procedure for Certain Hazardous Chemicals and Pesticides in International Trade.

https://www.jus.uio.no/lm/hazardous.chemicals.and.pesticides.prior.informe d.consent.trade.rotterdam.convention.1998/landscape.pdf. (Accessed 20 April, 2021)

Sustainable Pulse (2019, April 5), Malawi bans glyphosate herbicides after US cancer verdict. https://sustainablepulse.com/2019/04/05/malawi-bansimport-ofglyphosate-herbicides-after-us-cancer-verdict/ (Accessed 14 April 2021)

Williams, G.M., Aderma, E.M. et al. (2016), A review of the carcinogenic potential of glyphosate by four independent expert panels and comparison to the IARC assessment. Critical Reviews in Toxicology, 46 (sup1), 3-20, https://www.tandfonline.com/doi/pdf/10.1080/10408444.2016.1214677. (Accessed 14 March 2021) 